\title{
Do low-skilled youngsters get better jobs in countries where internal labour markets dominate?
}

Citation for published version (APA):

de Grip, A., \& Wolbers, M. H. J. (2003). Do low-skilled youngsters get better jobs in countries where internal labour markets dominate? Researchcentrum voor Onderwijs en Arbeidsmarkt, Faculteit der Economische Wetenschappen. ROA Research Memoranda No. 7E https://doi.org/10.26481/umaror.200307E

Document status and date:

Published: 01/01/2003

DOI:

10.26481/umaror.200307E

Document Version:

Publisher's PDF, also known as Version of record

\section{Please check the document version of this publication:}

- A submitted manuscript is the version of the article upon submission and before peer-review. There can be important differences between the submitted version and the official published version of record.

People interested in the research are advised to contact the author for the final version of the publication, or visit the DOI to the publisher's website.

- The final author version and the galley proof are versions of the publication after peer review.

- The final published version features the final layout of the paper including the volume, issue and page numbers.

Link to publication

\footnotetext{
General rights rights.

- You may freely distribute the URL identifying the publication in the public portal. please follow below link for the End User Agreement:

www.umlib.nl/taverne-license

Take down policy

If you believe that this document breaches copyright please contact us at:

repository@maastrichtuniversity.nl

providing details and we will investigate your claim.
}

Copyright and moral rights for the publications made accessible in the public portal are retained by the authors and/or other copyright owners and it is a condition of accessing publications that users recognise and abide by the legal requirements associated with these

- Users may download and print one copy of any publication from the public portal for the purpose of private study or research.

- You may not further distribute the material or use it for any profit-making activity or commercial gain

If the publication is distributed under the terms of Article $25 \mathrm{fa}$ of the Dutch Copyright Act, indicated by the "Taverne" license above, 
Do Low-Skilled Youngsters get Better Jobs in Countries where Internal Labour Markets Dominate?

ROA-RM-2003/7E

Andries de Grip and Maarten H.J. Wolbers

Research Centre for Education and the Labour Market

Faculty of Economics and Business Administration

Maastricht University

Maastricht, November 2003 
ISBN 90-5321-381-3

Sec03.175.doc 


\section{Contents}

Page

Abstract

Acknowledgement

1 Introduction 1

2 Internal and occupational labour markets 2

3 Data and variables used 4

4 Empirical analysis 6

5 Conclusion 9

$\begin{array}{ll}\text { References } & 10\end{array}$

Appendix 



\begin{abstract}
In this paper, we analyse to what extent the quality of the jobs of low-skilled young workers is affected by the labour market structure in various European countries. We focus on the differences between countries in which internal labour markets (ILM) are prevalent and countries in which occupational labour markets (OLM) dominate. We expect that low-skilled young workers in OLM countries have no access to skilled jobs and therefore only find employment in the secondary segment of the labour market, whereas in ILM countries lowskilled young workers have opportunities to develop their skills in firm internal labour markets when they succeed in entering these markets in times that the economy is booming. The results of our empirical analysis show that low-skilled youngsters are indeed better off in ILM countries than in OLM countries, with respect to the permanency of a job, employment in non-elementary jobs as well as participation in continuing vocational training. However, in ILM countries low-skilled young workers are more often involuntary employed in part-time jobs than in OLM countries. With respect to the likelihood of employment in elementary jobs and participation in continuing vocational training the ILM versus OLM contrast is, as expected, larger in manufacturing, where internal labour markets more frequently occur, than in the service sector.
\end{abstract}

\title{
Acknowledgement
}

We would like to thank Frank Cörvers, Hans Heijke and Philip Marey for their useful comments on an earlier draft of this paper. 



\section{Introduction}

Patterns of labour market entry differ considerable across European countries. There are marked cross-national differences not only in terms of youth unemployment, but also in terms of the quality of the jobs in which young people are employed (Ryan, 2001; Müller and Gangl, 2003). In addition, the upgrading of skill 'requirements' in most occupational fields threatens the labour market position of especially low-skilled young workers who are crowded out of their traditional occupational domains (Borghans and De Grip, 2000). This means that they are either locked up in low-quality jobs with flexible contracts that further weaken their labour market position, or crowded out of employment entirely. De Grip, Hoevenberg and Willems (1997) show that an increasing share of the workforce in EU Member States is employed in 'atypical jobs': part-time jobs and temporary contracts. This atypical employment is highly concentrated among low-skilled and young workers.

At this point, however, there may be a difference between the position of low-skilled young workers in manufacturing and the service sector, because of a difference in the speed of the upgrading process between these two sectors and the outsourcing of low-skilled work, in for instance catering and cleaning, from manufacturing firms to firms that provide these services to other firms. More important may be the difference in the quality of the jobs of lowskilled young workers due to the way in which firms recruit labour market entrants for skilled jobs. Here a distinction can be made between (firm-)internal labour markets (ILM) and occupational labour markets (OLM). Internal labour markets may offer more career opportunities for low-skilled labour market entrants in as far as they offer opportunities for low-skilled youngsters to participate in firm-specific training, whereas in occupational labour markets - characterized by a more or less close match between formal vocational qualifications and particular occupations - it is almost impossible for low-skilled young workers to enter as employment in these jobs is only open for skilled workers with a particular vocational background. ${ }^{1}$

In this paper, we analyse to what extent the quality of the jobs of low-skilled young workers is affected by the labour market structure in various European countries. In our analysis we indicate the quality of the jobs by (1) the level of the job, (2) the durability of the labour contract, (3) whether workers are forced to accept part-time jobs and (4) the participation in continuing vocational training. We concentrate on the difference between countries in which internal labour markets are prevalent and countries in which occupational labour markets dominate. We expect that low-skilled young workers in OLM countries have no access to skilled jobs and therefore only find employment in the secondary segment of the labour market, whereas in ILM countries low-skilled workers have opportunities to develop their skills in firm-internal labour markets when they succeed in entering an ILM in a period when the economy is booming. ${ }^{2}$ Moreover, we expect that the differences between ILM and OLM countries are larger in manufacturing than in services as in the manufacturing

1. It should be noted, however, that in countries in which vocational education is organized in an apprenticeship system youngsters with low abilities might have more opportunities to obtain a certified vocational background.

2. Estimation results of Dekker, De Grip and Heijke (2002) indicate that also the secondary labour market segment is used as a stepping stone for a job opening in the internal labour market. 
sector firms more often have an internal labour market, as there are more large firms and the capital intensity of production is usually much higher there. For the empirical analysis, we use data from the European Union Labour Force Survey (EU LFS) covering the period 19881997.

The paper is organized as follows. In section 2 we discuss the main characteristics of ILM and OLM arrangements and the expected implications of these two labour market structures for the quality of the jobs of low-skilled young workers. Section 3 discusses the data and the variables used in the empirical analysis. In section 4 the results of the empirical analysis on the quality of the jobs of low-skilled young workers in various European countries are presented. Section 5 concludes.

\section{Internal and occupational labour markets}

Labour market segmentation theory splits the labour market up into a primary segment containing the 'good' jobs and a secondary segment with bad, unstable jobs. Following Doeringer and Piore (1971), several authors subdivide the primary segment into internal labour markets (ILM) and occupational labour markets (OLM). Internal labour markets offer skilled jobs, which require firm-specific skills. On-the-job training is the most efficient way of obtaining these skills. Internal labour markets therefore offer better training facilities and internal career paths. Occupational labour markets refer to jobs that require specialized vocational training rather than firm-specific training. In general, internal promotions to higher job levels are scarce.

For low-skilled young workers it is difficult to find employment in the primary segment of the labour market as they are in the tail of the labour queue. However, at this point there is a difference between internal and occupational labour markets. In occupational labour markets young workers without the required qualifications for a particular occupation will not be recruited for jobs, whereas in internal labour markets low-skilled young workers will be recruited for jobs in the primary segment of the labour market, in particular in times of a booming economy. In internal labour markets both low and high-skilled labour market entrants have to acquire the firm-specific skills required to be productive in their job if they are recruited for a job. Employers only assume that low-skilled workers have a lower trainability than high-skilled workers which gives them a lower rank in the "labour queue" (Thurow, 1975). This offers low-skilled workers opportunities to find a job in an internal labour market in a period when employers have difficulties to recruit new workers. Moreover, as Dekker, De Grip and Heijke (2002) show, the secondary segment of the labour market has more and more become a 'waiting room' for the primary segment of the labour market in which workers can signal their abilities and motivation for a position in an internal labour market.

Marsden (1990) applies these labour market segmentation concepts to the societal level by giving a macro level characterization of national labour markets in terms of ILM and OLM countries. As Gangl (2001) notes, the key difference between the two is whether or not a country has an educational system providing occupational specific skills. Although in all countries there will be a co-existence of both ILM and OLM segments, the relative importance of either segment varies between countries to such an extent that in most 
countries one segment is prevalent in the economy (Eyraud, Marsden and Silvestre, 1990). Marsden's approach, tailored for international comparative research, therefore assumes that either market system can be treated as a systematic property of national economies. For the sake of conceptual clarity Gangl (2001) prefers to use the term 'arrangement' rather than 'segmentation', as the former term could better be understood as an ideal type representing an underlying continuum. ${ }^{3}$

The structure of the educational system in a country determines the recruitment process and the patterns of labour mobility in a country. From this point of view Gangl (2001) characterizes various European countries as ILM or OLM by means of a cluster analysis based on several indicators on labour mobility, recruitment behaviour, structure of unemployment in early career and career patterns of attainment. In ILM countries there is, for instance, an experience graded pattern of upward job mobility, whereas OLM countries are characterized by an immediate close match between the vocational background acquired in initial education by labour market entrants and the occupation they are employed in. In the former countries, worker-job matches are primarily achieved by means of firminternal training, and therefore, labour market entry in ILM systems can be described as "much less tightly structured by education, less orderly, more amenable to career contingencies and discretionary employer behaviour" (Gangl, 2001: 474).

It appears from this cluster analysis that countries where education and training systems are strongly vocationally oriented, are clearly separated from countries that do not have such training arrangements in initial education. Belgium, Finland, France, Ireland, Sweden, and the United Kingdom are characterized as countries in which internal labour markets are prevalent, opposed to Austria, Denmark, Germany and the Netherlands in which occupational labour markets dominate. In addition, the Southern European countries (Greece, Italy, Portugal, and Spain) are identified as a distinct, third cluster without any substantive explanation of the pattern the various indicators show, although Spain has some characteristics of an ILM arrangement.

Although the labour market integration of skilled labour market entrants is assumed to be smoother in OLM countries than in ILM ones (see for instance Kerckhoff, 1995; Marsden and Ryan, 1995; Müller and Shavit, 1998), we expect opposite effects for lowskilled young workers. As mentioned above, we expect that low-skilled young workers have better opportunities to get a job in the primary segment of the labour market and to stay employed in countries that are dominated by internal labour markets than in countries characterized by occupational labour markets for which low-skilled workers are not qualified.

In addition, labour market segmentation theory states that particularly large firms have internal labour markets as these firms have more stable product markets than small firms. Large firms are therefore more able to offer their workers employment security and opportunities for firm-internal promotions. Moreover, these large firms usually have a higher capital intensity of their production process, which makes it more important for these firms to have an internal labour market instead of offering instable secondary jobs in which the commitment of the workers to the firm is usually low (Piore, 1975; Dekker, De Grip and Heijke, 2002). So, we expect that internal labour markets more frequently occur in

3. Actually the distinction we make between ILM and OLM countries can be interpreted as a measure of the extent to which a country has each labour market structure. 
manufacturing than in services, because in manufacturing firms are on average larger and the capital intensity of the production process is usually much higher than in services.

Summing up, we can formulate two hypotheses concerning the cross-national variation in the quality of the jobs of low-skilled young workers:

1. In ILM countries the quality of the jobs of low-skilled young workers is better than in OLM countries;

2. The better quality of the jobs of low-skilled young workers in ILM countries is more distinct in manufacturing than in services.

In our analysis we focus on the quality of the jobs offered to the low-skilled young workers as it is characterized by the level of the job, the durability of the labour contract, whether workers are forced to accept part-time jobs and the opportunities to participate in continuing vocational training.

\section{Data and variables used}

The data we used for the empirical analysis come from the European Union Labour Force Survey (EU LFS) data for the period 1988-1997. The EU LFS is a combination of the original Labour Force Survey (LFS) as held annually in the EU member states. The EU LFS constitutes the best available data set on workers' quality of the jobs in the EU, because of its scale and its comparability between countries. We exclude the countries Austria, Sweden and Finland from the analysis, since data for these countries are only available since 1995 (due to their more recent membership of the European Union). Luxembourg is excluded from the analysis due to small sample sizes.

Young workers are defined as those individuals aged 15-34 years old. In addition, we selected only those youngsters who have left initial education within the past ten years - in order to analyse a cohort of recent entrants into the labour force. Since actual information on the age of leaving initial education is not available in the data set, we approximated the age of leaving education by means of the average graduation age for a particular level of education in a country. Furthermore, the EU LFS data set is based on the regular ILO definition about the labour force (ILO, 1990). This implies that individuals who are currently both in employment and in initial education or training (i.e. working students or young people participating in an apprenticeship programme) are counted as employed, whereas their main activity actually is student. Therefore, a small modification to the ILO definition is applied in this paper. All people who were employed at the time of the survey, but who were in initial education at the same time, are excluded from the active labour force.

Four aspects of the quality of the jobs of low-skilled young workers are analysed. First of all, we look at the permanency of the job by distinguishing between permanent and temporary jobs. A temporary position reflects a job with a contract of limited duration. Secondly, the probability of being in involuntary part-time employment is analysed. This measure refers to workers who have a part-time job because they could not get a full-time job. It should be noted, however, that the share of young workers in involuntary part-time employment is less than 20 per cent of all part-time workers in the countries under investigation. Thirdly, we 
determine the likelihood of having an elementary job. Elementary jobs refer to the lowest level jobs that do not require any skills. In labour market segmentation theory elementary jobs are characterized as the secondary segment of the labour market, which offers the workers usually bad instable jobs without any career perspectives (Doeringer and Piore, 1971). Employment in an elementary job is based on the first-digit level of the International Standard Classification of Occupations (ISCO-88 (COM)) (ILO, 1990b). ${ }^{4}$ Fourthly, we look at the training activities of workers in the last four weeks before the survey. Training activities are restricted here to participation in continuing vocational training to advance or change the working career. We analyse these four aspects of the quality of the jobs of low-skilled young workers in separate models as the data we have are split into different sets of variables that do not allow us to take account of the covariance in the error terms that may occur in as far there is a trade-off between the different aspects of the labour market considered (Cf. Adam Smith's "compensating wages").

To estimate the effects of the labour market structure, we specify the grouping of countries as proposed by Gangl (2001) that represent the main different institutional arrangements affecting the labour market entry of young workers in Europe. ${ }^{5}$ As mentioned in the previous section, Belgium, France, the United Kingdom and Ireland are defined as ILM countries. Germany, Denmark and the Netherlands, by contrast, are considered as OLM countries. As a third group, we combine the Southern European countries Greece, Italy, Spain and Portugal.

Industrial sectors are defined on the basis of the general industrial classification of economic activities (NACE Rev. 1) (EUROSTAT, 1996). We here distinguish between the sectors manufacturing (including the sections Mining and quarrying, Electricity, gas and water supply and Construction; sections C-F) and services (sections G-Q).

The level of education attained by workers is measured in terms of ISCED (UNESCO, 1975). Steedman and McIntosh (2001) show that ISCED2 is the most adequate cut-off point for determining the group of low-skilled workers. Low-skilled workers are therefore defined as individuals with lower secondary education (ISCED0-2) at most. Higher skilled workers are those with a diploma at the ISCED3 level or higher.

Gender differences are taken into account by distinguishing between men and women. The number of years since leaving education is included in the analysis to correct for differences in working experience. This variable is measured as the difference between the age of leaving education and the age at the time of the survey and it ranges between 0 and 10 years. Macro economic conditions at the time of the survey are controlled for, by using the aggregate unemployment level in a country in a given year. The unemployment figures were published in OECD (2001).

4. Since the occupational information collected in the period 1988-1991 does not provide sufficient comparability between countries, the analysis of being employed in an elementary job is restricted to the years 1992-1997.

5. Although there are some national differences within each country cluster, it seems that these country differences are minor to the clear contrasts between OLM, ILM and Southern European countries. Therefore, we ignore this within-cluster cross-country variation in the present analysis. 


\section{Empirical analysis}

We test the two formulated hypotheses by means of multivariate analyses on the various aspects of the quality of the job of the low-skilled workers in ILM and OLM countries. In this section we will show the estimation results of these analyses on the odds to be employed in (1) a temporary job, (2) an involuntary part-time job, (3) an elementary job and (4) the participation in continuing training, respectively. Each time we make separate estimates for manufacturing and services. In the specification of our empirical analyses we include interaction terms between the labour market structure and the level of education of the workers. This enables us to distinguish between the effects of the labour market structure on the quality of the job for low-skilled and higher-skilled young workers.

In Table 1 the results of logistic regression analysis of being temporary employed are presented. The estimation results show that low-skilled young people in OLM countries more often have a temporary job than low-skilled young workers in ILM countries. This finding holds for both manufacturing and services and, thus, corroborates our first hypothesis. The estimation results also show that the contrast between ILM and OLM countries with respect to temporary employment is larger among low-skilled young workers than among higher educated young workers. ${ }^{6}$ However, the difference between OLM and ILM countries in lowskilled workers' chance to be temporary employed is larger in services than in manufacturing. According to table A1 of the appendix, the difference between the manufacturing sector and the service sector in the effect of the labour market structure on the odds of lowskilled workers to be temporary employed is statistically significant. This finding falsifies the second hypothesis.

In addition, the results clearly demonstrate that women are less likely to be employed on a temporary basis than men. Furthermore, the number of years since leaving education has a negative effect on the odds of being temporary employed. Young workers who left education a longer time ago have less often a temporary job than those who left education recently. This indicates that for some workers temporary employment merely occurs in the first years of their working career (cf. Dekker, De Grip and Heijke, 2002). Finally, the findings show that macro economic conditions matter with respect to temporary employment. The higher the current aggregate unemployment rate is, the larger the likelihood of being temporary employed.

Table 1 also shows the estimation results of the logistic regression analysis of being involuntary part-time employed. The results show that in OLM countries involuntary part-time employment among low-skilled young workers occurs less often than in ILM countries, but the ILM versus OLM contrast is smaller for low-skilled young workers than for higher educated youngsters. This finding holds for both manufacturing and services. ${ }^{7}$ These results do not confirm our two hypotheses.

6. Among low-skilled young workers in services, for instance, the odds of being temporary employed are $1.557\left(\mathrm{e}^{0.443}\right)$ times larger in OLM countries than in ILM ones. Among higher skilled young workers in the same sector, the corresponding odds are $1.245\left(\mathrm{e}^{0.443-224}\right)$.

7. However, as shown in table A1, the contrast between ILM and OLM countries does not differ significantly between manufacturing and services. 
Table 1

Results of logistic regression analysis of being temporary employed and/or being involuntary part-time employed: logit effects

\begin{tabular}{|c|c|c|c|c|}
\hline & \multicolumn{2}{|c|}{ Being temporary employed } & \multicolumn{2}{|c|}{$\begin{array}{l}\text { Being involuntary part-time } \\
\text { emploved }\end{array}$} \\
\hline & Manufacturing & Services & Manufacturing & Services \\
\hline Intercept & $-2.851^{* *}$ & $-2.113^{* *}$ & $-4.317^{* *}$ & $-3.218^{* *}$ \\
\hline \multicolumn{5}{|l|}{ Labour market structure } \\
\hline ILM & ref. & ref. & ref. & ref. \\
\hline OLM & $0.309^{* *}$ & $0.443^{* *}$ & $-0.453^{* *}$ & $-0.656^{* *}$ \\
\hline Southern Europe & $0.395^{\star *}$ & $0.493^{* *}$ & $-0.417^{* *}$ & $-1.025^{\star *}$ \\
\hline \multicolumn{5}{|l|}{ Level of education } \\
\hline Low skilled & ref. & ref. & ref. & ref. \\
\hline Higher skilled & $-0.637^{* *}$ & $-0.379^{* *}$ & $-0.478^{\star *}$ & $-0.527^{* *}$ \\
\hline \multicolumn{5}{|l|}{ Gender } \\
\hline Male & ref. & ref. & ref. & ref. \\
\hline Female & $-0.066^{* *}$ & $-0.074^{* *}$ & $0.826^{* *}$ & $0.841^{* *}$ \\
\hline Years since leaving education & $-0.151^{* *}$ & $-0.141^{* *}$ & $-0.049^{* *}$ & $-0.060^{* *}$ \\
\hline Aggregate unemployment rate & $0.190^{* *}$ & $0.137^{* *}$ & $0.024^{*}$ & $0.069^{* *}$ \\
\hline \multicolumn{5}{|c|}{ Level of education x labour market structure } \\
\hline Higher skilled x OLM & $-0.412^{* *}$ & $-0.224^{* *}$ & $-0.583^{* *}$ & -0.057 \\
\hline Higher skilled $x$ Southern Europe & $-0.129^{*}$ & $-0.367^{\star *}$ & $0.361^{*}$ & $0.220^{\star *}$ \\
\hline Model Chi ${ }^{2}$ & $11,317^{* *}$ & $12,374^{* *}$ & $333^{* *}$ & $2,915^{\star *}$ \\
\hline & 8 & 8 & 8 & 8 \\
\hline Pseudo $\mathrm{R}^{2}$ & 0.227 & 0.123 & 0.037 & 0.055 \\
\hline$N$ & 84,314 & 162,939 & 87,314 & 173,107 \\
\hline
\end{tabular}

${ }^{*}=\mathrm{p}<0.05 ;{ }^{* *}=\mathrm{p}<0.01$

ref. = reference category

Source: pooled EU LFS-data 1988-1997

Furthermore, the results show that women are more likely to be involuntary part-time employed than men. The number of years since leaving education matters as well: it has a negative effect on the probability of being involuntary part-time employed. Again, this indicates that some workers are only employed in low-quality jobs in the first years of their working career. Finally, the aggregate unemployment rate affects involuntary part-time employment. The higher the unemployment level is, the larger the likelihood that young workers are part-time employed on an involuntary basis.

Table 2 shows the estimation results of the odds to be employed in an elementary job. These elementary jobs refer to the lowest level jobs that do not require any skills. The table shows that low-skilled young workers in ILM countries are less likely to be employed in an elementary job than low-skilled youngsters in OLM countries. Moreover, the contrast between ILM and OLM countries is more distinct in manufacturing than in the service sector. Table A1 shows that this difference in the effect size is statistically significant. These findings support our two hypotheses. 
Table 2

Results of logistic regression analysis of being employed in an elementary job and/or participating in continuing vocational training: logit effects

\begin{tabular}{|c|c|c|c|c|}
\hline & \multicolumn{2}{|c|}{$\begin{array}{l}\text { Being employed in an } \\
\text { elementary job }\end{array}$} & \multicolumn{2}{|c|}{$\begin{array}{l}\text { Participating in continuing voc. } \\
\text { training }\end{array}$} \\
\hline & Manufacturing & Services & Manufacturing & Services \\
\hline Intercept & $-1.979^{* *}$ & $-1.851^{* *}$ & $-0.492^{* *}$ & $-0.581^{* *}$ \\
\hline \multicolumn{5}{|l|}{ Labour market structure } \\
\hline ILM & ref. & ref. & ref. & ref. \\
\hline OLM & $0.957^{\star \star}$ & $0.737^{\star \star}$ & $-0.672^{* *}$ & $-0.412^{\star *}$ \\
\hline Southern Europe & $-0.187^{* *}$ & $-0.254^{* *}$ & $-2.671^{* *}$ & $-2.365^{\star *}$ \\
\hline \multicolumn{5}{|l|}{ Level of education } \\
\hline Low skilled & ref. & ref. & ref. & ref. \\
\hline Higher skilled & $-1.341^{* *}$ & $-1.666^{\star *}$ & $0.527^{* *}$ & $0.453^{* *}$ \\
\hline \multicolumn{5}{|l|}{ Gender } \\
\hline Male & ref. & ref. & ref. & ref. \\
\hline Female & $-0.131^{\star \star}$ & $-0.188^{* *}$ & $-0.088^{* *}$ & $-0.162^{\star *}$ \\
\hline Years since leaving education & $-0.069^{* *}$ & $-0.036^{* *}$ & $-0.076^{* *}$ & $-0.048^{* *}$ \\
\hline Aggregate unemployment rate & $0.063^{\star *}$ & $0.057^{* *}$ & $-0.147^{* *}$ & $-0.109^{* *}$ \\
\hline \multicolumn{5}{|l|}{$\begin{array}{l}\text { Level of education } x \text { labour market } \\
\text { structure }\end{array}$} \\
\hline Higher skilled x OLM & $-0.677^{\star *}$ & $-0.504^{\star *}$ & $-0.343^{* *}$ & $-0.142^{\star *}$ \\
\hline $\begin{array}{l}\text { Higher skilled } x \text { Southern } \\
\text { Europe }\end{array}$ & 0.129 & -0.029 & $1.633^{* *}$ & $1.592^{* *}$ \\
\hline Model Chi ${ }^{2}$ & $2,345^{\star *}$ & $5,846^{* *}$ & $3,985^{* *}$ & $6,722^{* *}$ \\
\hline & 8 & 8 & 8 & 8 \\
\hline Pseudo $\mathrm{R}^{2}$ & 0.101 & 0.126 & 0.108 & 0.072 \\
\hline $\mathrm{N}$ & 50,688 & 113,409 & 86,663 & 171,028 \\
\hline
\end{tabular}

${ }^{*}=p<0.05 ;{ }^{* *}=p<0.01$

ref. = reference category

Source: pooled EU LFS-data 1988-1997

Furthermore, we find that women are less often working in an elementary job than men. Also the number of years since leaving education has a negative impact: young workers who left education a longer time ago are less often employed in an elementary job than those who left school recently. This indicates that for some workers employment in elementary jobs is concentrated in their early working career (see for instance Lynch, 1993). Finally, the effect of the aggregate unemployment rate is significant: the worse the current labour market situation is, the higher the likelihood that labour market entrants work in an elementary job.

Table 2 also shows the estimation results on the likelihood that low-skilled youngsters participate in additional training activities. We find that in OLM countries the participation in continuing vocational training among low-skilled young workers is lower than in ILM countries. This corroborates our first hypothesis. Moreover, the results show that the difference in training participation of low-skilled workers between ILM and OLM countries is significantly larger in manufacturing than in services (for the statistical test of significance, see Table A1). This finding supports the second hypothesis. 
Furthermore, we find that female workers participate less often in continuing vocational training than male workers (cf. for instance Shields, 1998). The gender effect is stronger in services than in manufacturing. Also, the amount of working experience matters with respect to participation in continuing vocational training. The longer a person has left initial education, the smaller the likelihood that investments in continuing training are made. Finally, the estimation results demonstrate that high unemployment lowers participation in continuing vocational training. This shows that the investments in training activities are sensitive for cyclical fluctuations in the economy. An increase of 1 per cent in the aggregate unemployment rate coincides with a decrease of more than 10 per cent in the odds of participating in continuing vocational training. This finding holds for both manufacturing and services.

\section{Conclusion}

In this paper we analysed to what extent the quality of the jobs of low-skilled young workers is affected by the dominant labour market structure in various European countries. The focus of our analysis was on the likelihood of atypical employment (temporary contracts and involuntary part-time work), employment in unskilled elementary jobs and participation in continuing vocational training.

From labour market segmentation theory we derived the hypothesis that low-skilled young workers in countries that are characterized by occupational labour markets (OLM) have no access to skilled jobs and therefore only find employment in the secondary segment of the labour market, whereas in countries where internal labour markets (ILM) are dominant low-skilled young workers have opportunities to find a better quality job, as particularly when the economy is booming also low-skilled workers will obtain jobs in firm-internal labour markets, whereas in these countries the secondary labour market could function as a waiting-room for the internal labour markets. In addition, we hypothesized that the better quality of the jobs of low-skilled young workers in ILM countries is more distinct in manufacturing than in services.

The results of our empirical analysis show that, with respect to the permanency of a job, employment in unskilled elementary jobs and participation in continuing vocational training, low-skilled young workers are indeed better off in ILM countries than in OLM ones. However, in contrast to what we expected low-skilled young workers in ILM countries are more often involuntary employed in a part-time job than in OLM countries.

With respect to the odds of being employed in an elementary job and low-skilled workers' participation in continuing vocational training the ILM versus OLM contrast is, as expected, larger in manufacturing than in the service sector. However, there is no significant difference between manufacturing and the service sector in the odds of involuntary part-time employment in OLM and ILM countries, whereas in contrast to what we expected, the difference between OLM and ILM countries in low-skilled workers' chance to be temporary employed is larger in services than in manufacturing.

Our findings show that low-skilled young workers are indeed better off in countries where internal labour markets dominate than in countries characterized by occupational labour markets as the former offer these workers more opportunities to find a 'non-marginal' 
job in the primary segment of the labour market. The vulnerability of the least qualified youngsters in the labour market is indeed affected by a country's labour market structure. As the European economy more and more developes in the direction of a 'knowledge economy', the demand for higher job qualifications in most occupational fields will in general threaten the quality of the jobs of low-skilled workers in the sense that they are either locked up in poorly paid elementary jobs with flexible contracts or crowded out of employment entirely. This process of skills upgrading will, however, have less serious consequences for low-skilled young workers in ILM countries than in OLM ones, since the acquisition of occupational skills is organized differently between the two labour market structures. Internal labour markets where vocational training is organized on-the-job have the advantage "that workers are not so much restricted to narrowly defined occupational fields and that new generations of entrants can flexibly be directed to new and future-oriented occupational fields" (Blossfeld and Stockmann, 1999: 9). The question is, however, whether this advantage of on-the-job training for low skilled workers at labour market entry remains over the life course. Since on-the-job training is very firm specific, it may be irrelevant in case of inter-firm mobility and become obsolete due to rapidly changing skills requirements (De Grip and Van Loo, 2002). Vocational training organized in initial education via schools or apprenticeships, on the other hand, is much more standardized and, therefore, the acquired skills have high levels of consistency across firms or even industries, are transferable across employers and are recognized as such (Eyraud, Marsden and Silvestre, 1990; Shavit and Müller, 2000). This requires further research to provide more insight in the effects of different vocational training systems and, accordingly, different labour market structures on the risks of skill obsolescence of low-skilled older workers.

\section{References}

Borghans, L., A. de Grip (2000) (Eds.), The overeducated worker? The economics of skill utilization, Edward Elgar, Cheltenham.

Blossfeld, H-P., R. Stockmann (1999), The German dual system in comparative perspective, International Journal of Sociology, 28, 3-28.

Dekker, R., A. de Grip, H. Heijke (2002), The effects of training and overeducation on career mobility in a segmented labour market, International Journal of Manpower, 23,106-125.

Doeringer, P., M. Piore (1971), Internal labour markets and manpower analysis, Lexington Books, Heath, Lexington.

EUROSTAT (1996), Labour force survey. Methods and definitions 1998, Luxembourg, Office for Official Publications of the European Communities.

Eyraud, F., D. Marsden, J. Silvestre (1990), Occupational and internal labour markets in Britain and France, International Labour Review, 129, 501-517.

Gangl, M. (2001), European patterns of labour market entry. A dichotomy of occupationalized vs. nonoccupationalized systems, European Societies, 3, 471-494.

Grip, A. de, J. Hoevenberg, E. Willems (1997), Atypical employment in the European Union, International Labour Review, 136, 49-71. 
Grip, A. de, J. van Loo (2002), The Economics of Skills Obsolescence: A Review, in: A. de Grip, J. van Loo, K. Mayhew (Eds.), The Economics of Skills Obsolescence. Theoretical Innovations and Empirical Applications, Research in Labor Economics, 21, 1-26.

ILO (1990a), Statistical sources and methods [Volume 3: Economically active population, employment, unemployment and hours of work (household surveys), second edition.], Geneva: International Labour Organisation.

ILO (1990b), ISCO-88 International Standard Classification of Occupations, Geneva: International Labour Organisation.

Kerckhoff, A. (1995), Institutional arrangements and stratification processes in industrial societies, Annual Review of Sociology, 15, 323-347.

Lynch, L.M. (1993), Entry-Level Jobs: First Rung on the Employment Ladder or Economic Dead End?, Journal of Labor Research, 14, 249-263.

Marsden, D. (1990), Institutions and labour mobility. Occupational and internal labour markets in Britain, France, Italy and West-Germany, in: R. Brunetta and C. Dell'Aringa (Eds.), Labour relations and economic performance, Macmillan, Houndsmill, 414-438.

Marsden, D., P. Ryan (1995), Work, labour markets and vocational preparation: Anglo-German comparisons of training in intermediate skills, in: L. Bash, A. Green (Eds.), Youth, education and work, Kogan Page, London, 67-79.

Müller, W., M. Gangl (Eds.) (2003), Transitions from education to work in Europe: The integration of youth into EU labour markets, Oxford University Press, Oxford, forthcoming.

Müller, W., Y. Shavit (1998), The institutional embeddedness of the stratification process: a comparative study of qualifications and occupations in thirteen countries, in: Y. Shavit, W. Müller (Eds.), From school to work. A comparative study of educational qualifications and occupational destinations, Clarendon Press, Oxford, 1-48.

OECD (2001). Economic outlook. Paris: Organisation for Economic Co-operation and Development.

Piore, M. (1975), Notes for a theory of labor market stratification, in: R. Edwards, M. Reich, D. Gordon (Eds.), Labor market segmentation, Lexington Books, London, 125-150.

Ryan, P. (2001), The school-to-work-transition: A cross-national perspective. Journal of Economic Literature, 39, 34-92.

Steedman, H., S. McIntosh (2001), Measuring low skills in Europe: how useful is the ISCED framework?, Oxford Economic Papers, 53, 564-581.

Shavit, Y., W. Müller, (2000), Vocational secondary education. Where diversion and where safety net?, European Societies, 2, 29-50.

Shields, M. (1998), Changes in the determinants of employer-funded training for full-time employees in Britain, Oxford Bulletin of Economics and Statistics, 60, 189-214.

Thurow, L. (1975), Generating Inequality, Macmillan, New York.

UNESCO (1975), International Standard Classification of Education (ISCED), Paris: United Nations Educational, Scientific and Cultural Organization. 



\section{Appendix}

Table A1

Significance test of differences ${ }^{a}$ in the effects of the labour market structure for low-skilled young workers between manufacturing and services

ILM OLM Southern Europe

$\begin{array}{llcc}\text { Being temporary employed } & - & -0.134^{* *} & -0.098^{* *} \\ \text { Being involuntary part-time employed } & - & 0.203 & 0.608^{* *} \\ \text { Being in an elementary job } & - & 0.220^{* *} & 0.067 \\ \text { Participating in continuing vocational training } & - & -0.260^{* *} & -0.306^{* *}\end{array}$

$=p<0.05 ;{ }^{* *}=p<0.01$

$a=$ differences are calculated as $\beta_{\text {manufacturing }}-\beta_{\text {services. }}$. The $\mathrm{t}$-values of these differences are calculated as $\left(\beta_{\text {manufacturing }}-\beta_{\text {services }}\right) / \sqrt{ }\left(\operatorname{var}\left(\beta_{\text {manufacturing }}\right)+\operatorname{var}\left(\beta_{\text {services }}\right)\right)$.

ref. $=$ reference category

Source: pooled EU LFS-data 1988-1997 